\title{
Assessment of Spatio-Temporal Variation of Groundwater Quality in Udi-Ezeagu Watershed, Enugu Area Southeastern Nigeria
}

\author{
Tonia Nkiru Nwobodo ${ }^{1}$, Martin Atu Ngozika Anikwe ${ }^{2, ~ *, ~ K e v i n ~ E j i k e ~ C h u k w u ' ~}$ \\ ${ }^{1}$ Department of Geography and Meteorology, Enugu State University of Science and Technology, Enugu, Nigeria \\ ${ }^{2}$ Department of Agronomy and Ecological Management, Enugu State University of Science and Technology, Enugu, Nigeria \\ Email address: \\ anikwema@yahoo.co.uk (M. A. N. Anikwe), toniaonline007@yahoo.com (T. N. Nwobodo), chukwukevin2000@yahoo.com (K. E. Chukwu)
}

\section{To cite this article:}

Tonia Nkiru Nwobodo, Martin Atu Ngozika Anikwe, Kevin Ejike Chukwu. Assessment of Spatio-Temporal Variation of Groundwater Quality in Udi-Ezeagu Watershed, Enugu Area Southeastern Nigeria. International Journal of Environmental Monitoring and Analysis. Vol. 3, No. 4, 2015, pp. 210-217. doi: 10.11648/j.ijema.20150304.12

\begin{abstract}
This study was carried out to assess the spatio-temporal variation of groundwater quality in Udi-Ezeagu Watershed, Enugu Area, Southeastern Nigeria. The specific objectives were to determine the physical, chemical and microbiological characteristics of groundwater samples in space and time and to ascertain the quality of groundwater using the parameter in comparison with WHO permissible limits. A total of five (5) groundwater samples were collected in triplicates from boreholes located at Ninth Mile Corner, Obioma, Umuase, Abor and Akama-Amankwo at two different time scales. The samples were collected in April (before the onset of rainy season) and September (before the cessation of rainy season), in 2014. The groundwater samples were analyzed in the laboratory for their physical, chemical and microbiological characteristics. On comparing the results with standard values recommended by World Health Organization (WHO), it was discovered that most of the groundwater samples were within permissible limits with slight variation across the locations and in seasons. However, $\mathrm{pH}$ of the groundwater samples were not within the permissible limit of $6.50 \mathrm{mg} / 1-8.50 \mathrm{mg} / 1 \mathrm{in}$ four different locations which are Ninth Mile Corner, Umuase, Abor and Akama-Amankwo with pH values of 5.60, 6.20, 5.00 and 5.00 . Total hardness of the groundwater samples with values of $12.00 \mathrm{mg} / 1,58.50 \mathrm{mg} / 1,45.00 \mathrm{mg} / 1,15.50 \mathrm{mg} / 1 \mathrm{and} 11.70 \mathrm{mg} / 1 \mathrm{in}$ the dry season and $8.00 \mathrm{mg} / 1,59.00 \mathrm{mg} / 1,43.00 \mathrm{mg} / 1,12.00 \mathrm{mg} / 1$ and $7.00 \mathrm{mg} / 1$ respectively in the rainy season were not within the permissible limit of $100.00 \mathrm{mg} / \mathrm{l}-200.00 \mathrm{mg} / \mathrm{l}$ in all the locations and in the seasons for Ninth Mile Corner, Obioma, Umuase, Abor and Akama-Amankwo respectively. Magnesium hardness of the groundwater samples with values ranging from $1.50 \mathrm{mg} / \mathrm{l}-1.65$ in the dry season and $5.60 \mathrm{mg} / 1-6.80 \mathrm{mg} / \mathrm{l}$ respectively in the rainy season were slightly above the permissible limit of $1.00 \mathrm{mg} / \mathrm{l}$ in all the locations and in seasons. Total coliform were absent in all the locations during the dry season and was slightly in excess during the rainy season at $9^{\text {th }}$ Mile Corner and Abor with a value of 4.00 per $100 \mathrm{ml}$ against the permissible limit 3.00. The study found out that minimal treatment is required in the study area and recommends continuous monitoring of the groundwater supply to keep the quality in check.
\end{abstract}

Keywords: Groundwater Quality, Spatio-Temporal Variation, Udi-EzeaguWatershed, SE Nigeria

\section{Introduction}

Groundwater is the most important source of domestic, industrial and agricultural water supply in the world. Many countries in the Africa depend heavily on groundwater. Exploitation of surface water has reduced, ensuring an increasing reliance on groundwater abstraction due to increasing pollution with the concomitant rise in the cost of water treatment (Kortatsi, 2007). Groundwater is usually of excellent quality. Being naturally filtered in their passage through the ground, they are usually clear, colourless and free from microbial contamination and required minimal treatment (Ebrahim, 2011). Unfortunately, these valuable resources are now posed by an ever-increasing number of soluble chemicals from urban and industrial activities and from modern agricultural practices. The quality of groundwater depends on several factors, including climate, soil characteristics, manner of circulation of groundwater through the rock type and topography of the area (Onwuka et $a l$. , 2010). The chemical composition of groundwater 
depends not only on natural factors such as lithology of aquifer, the quality of recharge waters and types of interactions between water aquifer, but also on anthropogenic activities, which can alter fragile groundwater systems polluting them or by changing hydrological cycle ( Helena et $a l .$, 2002). The quality of groundwater is constantly changing in response to daily, seasonal and climatic factors. Continuous monitoring of water quality parameters is highly crucial because changes in the quality of water have far reaching consequences in terms of its effects on man and biota (Sarukkalige, 2012). Enugu metropolis Nigeria, largely depends on ground water from Udi/Ezeagu watershed as alternative source of potable water supply. The increasing groundwater usage is based on the assumption that groundwater is less polluted since water is filtered and percolated down the ground. However, numerous studies have shown otherwise. According to Ngaje et al (2010) problem of acid mine drainage have been reported in some areas, especially the coal mining areas in Enugu. Fetter, (1993) pointed out that groundwater contamination may cause various disease and other problems. Hence, there is need to assess the sustainability of water used for domestic purposes and need to assess the groundwater quality based on location and time. The main objective of this work is to assess the spatio-temporal variation of groundwater quality in Udi/Ezeagu watershed, Enugu Area Southeastern Nigeria.
The specific objectives were to determine the physical, chemical and microbiological characteristics of groundwater quality in space and time and to ascertain the quality of groundwater using the parameters in comparison with WHO permissible limits.

\section{Materials and Methods}

\subsection{Study Area}

Udi/Ezeagu watershed is a large watershed within Enugu area, southeastern Nigeria. It is situated within longitudes $7^{0} 9^{\prime} \mathrm{E}$ and $7^{0} 28^{\prime} \mathrm{E}$ and latitudes $6^{0} 12^{\prime} \mathrm{N}$ and $6^{0} 41^{\prime} \mathrm{N}$ (Fig.1) in the Southeastern part of Nigeria encompassing an area of about $897 \mathrm{~km}^{2}$, with an elevation ranging from $231 \mathrm{~m}$ to $500 \mathrm{~m}$ above mean sea level. Rainfall is seasonal with a wet rainy season and a dry harmattan season controlled by the north-east and south-west wind. The soils are made up of shallow and stony lithosols found on the steep slopes of the cuesta and often left uncultivated and Ultisols in the lower part (Anikwe et al 2007). The soil erosion is rampant in the area and is as a result of both physical and anthropogenic causes. The study area is underlain by three major geological formation; the Mamu, Ajali and Nsukka formations respectively. (Fig 2)

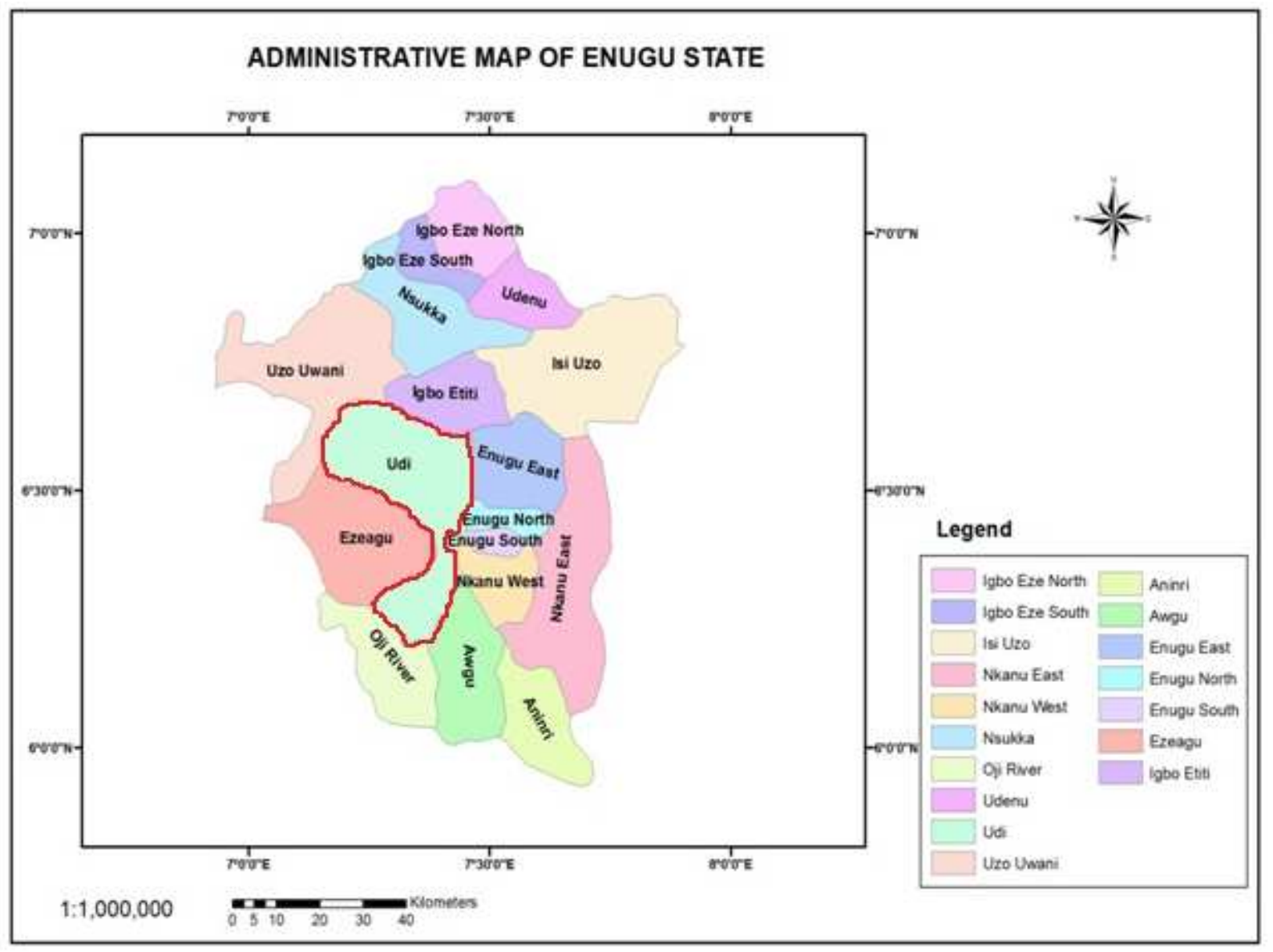

Figure 1. Map showing the study area, Udi Local Government Area (Source: ASTAL Uyo, Nigeria). 


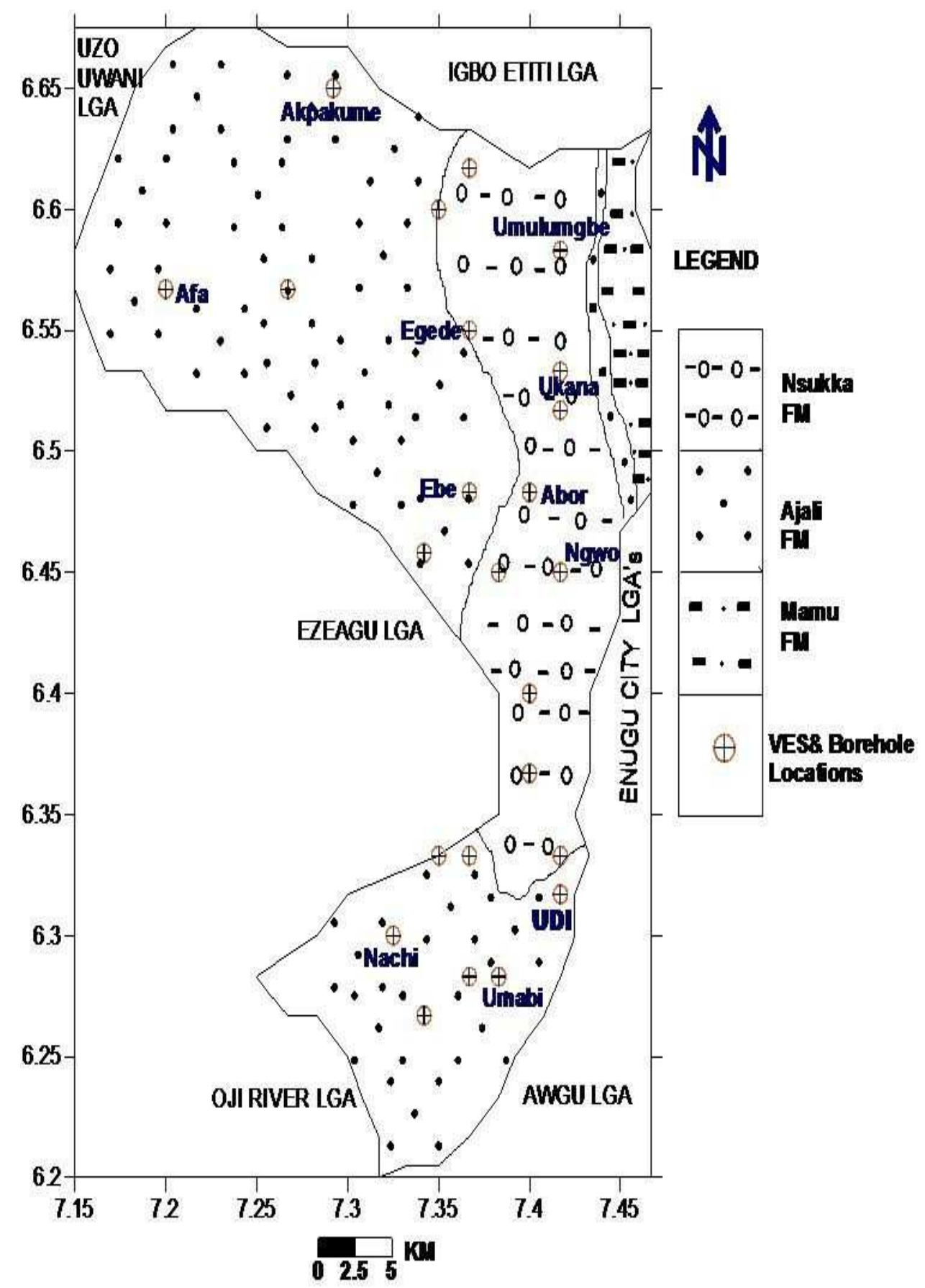

Figure 2. Geologic map of the Udi area (Source: Eze et al, 2013).

The Mamu formation, previously known as lower coal measures (Reyment, 1965), underlies the eastern part of the study area. It consists of fine-medium grained white to grey sandstones, shaly sandstones, sandy shales, grey mudstones, shales and coal seams. The sandstone consists of thick friable, poorly sorted arkosic sandstones typically white in colour but sometimes iron stained. The Nsukka formation, previously known as the upper coal measures ( Reyment, 1965), lies comfortably on Ajali sandstone. The lithology is very similar to that of Mamu formation and consists of an alternating succession of sandstone, dark shale and sandy shale, within coal seams at various horizons. The Ajali sandstone ranks the second most prolific aquifer in Nigeria after the coastal plain sands. Its permeability and high storage capacity enables it to absorb all the run-off resulting from rainfall. It comprises mainly a water table aquifer, and also has semi-confined aquifer where fingers of clays occur in appreciable thicknesses (Offodile, 2002).

\subsection{Field Study}

A total of five groundwater samples were collected during the dry season (April) and rainy season (September) respectively at five different sampling sites in the study Area. Groundwater samples were collected in triplicates 
from Ninth Mile Corner $\left(6^{0} 43^{\prime} 2.94^{\prime} \mathrm{N} ; 7^{0} 40^{\prime} 6.27^{\prime} \mathrm{E}\right)$, Obioma $\left(6^{\circ} 35^{\prime} 8.54^{\prime} \mathrm{N} ; 7^{\circ} 39^{\prime} 3.53^{\prime} \mathrm{E}\right), \mathrm{Umuase}$ $\left(6^{\circ} 41^{\prime} 46.58^{\prime} \mathrm{N} ; 7^{\circ} 25^{\prime} 13.78^{\prime} \mathrm{E}\right)$, Abor $\left(6^{\circ} 47^{\prime} 4.37^{\prime} \mathrm{N} ; 7^{\circ} 41^{\prime} 4.66^{\prime} \mathrm{E}\right)$ and Akama-Amankwo (6 44'3. 41' N;7 42'7. 29'E) in April, 2014 representing dry and rainy season respectively. The parameters analyzed were twenty-four (24) in number which include: Temperature, $\mathrm{pH}$, Electrical conductivity, Total solids, Turbidity, Colour, Total dissolved solids, Total suspended solids, Total hardness, Magnesium hardness, Chlorides, Chlorides as Nacl, Sulphates, Nitrate, Silica, Total alkalinity, Calcium hardness, Iron, Calcium ion, Magnesium ion, Manganese, Total plate count, Total coliform and E-coli. An in situ test was carried out using potable digital meter for Temperature, $\mathrm{pH}$, Total dissolved solids and Electrical conductivity. The instruments used for measuring the Temperature was thermometer and HANNA instrument with models, pHep was used in measuring $\mathrm{pH}$ and H196301 used in measuring Electrical conductivity and Total dissolved solids. The co-ordinates and elevations of the sampling pointes were recorded using Global Positioning System (GPS). The groundwater samples were collected in a clean 1.5 litre plastic jar with screw caps and packed in a cooler and transported to the laboratory immediately. The groundwater samples were stored in the refrigerator at $4^{0} \mathrm{C}$ until analysis was completed. The twenty-four parameters were analyzed according to the standard methods of APHA-AWWA-WEF (2012).

\section{Results}

\subsection{Spatial Distribution of Groundwater Samples in the Study Area During the Dry Season}

Table 3.1 showed that the mean temperature values of groundwater samples obtained from Ninth Mile Corner, Obioma, Umuase, Abor and Akama-Amankwo were $21.00^{\circ} \mathrm{C}$, $19.50^{\circ} \mathrm{C}, 21.50^{\circ} \mathrm{C}, 18.50^{\circ} \mathrm{C}$ and $19.00^{\circ} \mathrm{C}$. The results showed variation in temperature in the various sites. The mean $\mathrm{pH}$ values of groundwater samples obtained from $9^{\text {th }}$ Mile Corner, Obioma, Umuase, Abor and Akama-Amankwo were 7.02, $7.30,7.50,7.50$ and 8.11 . The results showed variation in space as shown in Table 3.1. The mean values of electrical conductivity of groundwater samples obtained from Ninth Mile Corner, Obioma, Umuase, Abor and Akama-Amankwo respectively were $50.70 \mu \mathrm{s} / \mathrm{cm}, 198.80 \mu \mathrm{s} / \mathrm{cm}, 175.80 \mu \mathrm{s} / \mathrm{cm}$, $80.35 \mu \mathrm{s} / \mathrm{cm}$ and $20.70 \mu \mathrm{s} / \mathrm{cm}$ as shown in Table 3.1 . Table 3.1 also shows the mean values of Total Solids from Ninth Mile Corner, Obioma, Umuase, Abor and Akama-Amankwo were $52.28 \mathrm{mg} / \mathrm{L}, \quad 154.20 \mathrm{mg} / \mathrm{L}, \quad 132.08 \mathrm{mg} / \mathrm{L}, \quad 73.12 \mathrm{mg} / \mathrm{L}$ and $29.00 \mathrm{mg} / \mathrm{L}$. These results showed variation from location to location.

Table 3.1. Spatio-Temporal Variation of Physical Properties of Groundwater Quality Characteristics in the Study Area.

\begin{tabular}{|c|c|c|c|c|c|c|c|c|c|c|c|c|c|}
\hline S/no & Parameters & Units & Who std & \multicolumn{10}{|c|}{ sample result } \\
\hline & \multirow{5}{*}{$\begin{array}{l}\text { Sample } \\
\text { identification } \\
\text { / location }\end{array}$} & & & \multicolumn{2}{|l|}{ A } & & & & \multicolumn{2}{|l|}{$\mathrm{E}$} \\
\hline & & & & \multirow{2}{*}{\multicolumn{2}{|c|}{$\begin{array}{l}\text { Ninth Mile } \\
\text { Corner }\end{array}$}} & & & & & \multirow{2}{*}{\multicolumn{2}{|c|}{ Ubiekpo Abor }} & \multirow{2}{*}{\multicolumn{2}{|c|}{$\begin{array}{l}\text { Akama Amankwo } \\
\text { Ngwo-uno }\end{array}$}} \\
\hline & & & & & & \multicolumn{2}{|l|}{ Obioma } & \multicolumn{2}{|c|}{ Umuase Ngwo } & & & & \\
\hline & & & & \multicolumn{2}{|c|}{ Seasons } & \multicolumn{2}{|l|}{ Seasons } & \multicolumn{2}{|c|}{ Seasons } & \multicolumn{2}{|c|}{ Seasons } & \multicolumn{2}{|c|}{ Seasons } \\
\hline & & & & Dry & Rainy & Dry & Rainy & Dry & Rainy & Dry & Rainy & Dry & Rainy \\
\hline \multirow{13}{*}{1.} & Physical & & & & & & & & & & & & \\
\hline & Analysis & & & & & & & & & & & & \\
\hline & Temperature & ${ }^{\circ}$ Celsius & ${ }^{\circ}$ Celsius & 21.00 & 29.50 & 19.50 & 29.00 & 21.50 & 26.00 & 18.50 & 26.00 & 19.00 & 26.50 \\
\hline & $\mathrm{pH}$ & & $6.50-08.50$ & 7.02 & 5.60 & 7.30 & 6.80 & 7.50 & 6.20 & 7.30 & 5.00 & 8.11 & 5.50 \\
\hline & $\begin{array}{l}\text { Electrical } \\
\text { conductivity }\end{array}$ & $\begin{array}{l}\text { Microh } \\
\mathrm{ms} / \mathrm{cm}\end{array}$ & 1000.00 & 50.70 & 71.30 & 198.50 & 233.00 & 175.80 & 201.00 & 80.35 & 105.70 & 20.70 & 41.60 \\
\hline & Total Solids & $\mathrm{mg} / \mathrm{L}$ & 1000.00 & 48.49 & 46.38 & 155.29 & 151.50 & 133.19 & 130.69 & 70.42 & 68.74 & 28.12 & 27.07 \\
\hline & Turbidity & NTU & 5.00 & 0.00 & 0.00 & 0.00 & 0.00 & 0.00 & 0.00 & 0.00 & 0.00 & 0.00 & 0.00 \\
\hline & Colour & TCU & 50.00 & 2.45 & 4.00 & 2.10 & 4.00 & 2.65 & 5.00 & 2.00 & 4.00 & 2.05 & 4.00 \\
\hline & Total & & & & & & & & & & & & \\
\hline & Dissolved & $\mathrm{mg} / \mathrm{L}$ & 500.00 & 48.48 & 46.35 & 155.25 & 151.45 & 133.15 & 130.65 & 70.40 & 68.71 & 28.10 & 27.04 \\
\hline & Solids & & & & & & & & & & & & \\
\hline & Total & & & & & & & & & & & & \\
\hline & $\begin{array}{l}\text { Suspended } \\
\text { solids }\end{array}$ & $\mathrm{mg} / \mathrm{L}$ & & 0.01 & 0.03 & 0.04 & 0.05 & 0.04 & 0.04 & 0.015 & 0.03 & 0.018 & 0.03 \\
\hline
\end{tabular}

Table 3.2 showed that the mean values of Total Hardness of the groundwater samples in the sites viz. Ninth Mile Corner, Obioma, Umuase, Abor and Akam-Amankwo were $12.00 \mathrm{mg} / \mathrm{L}, \quad 58.50 \mathrm{mg} / \mathrm{L}, \quad 45.00 \mathrm{mg} / \mathrm{L}, \quad 15.50 \mathrm{mg} / \mathrm{L} \quad$ and $11.70 \mathrm{mg} / \mathrm{L}$ respectively and mean values of Total Alkalinity of the groundwater samples from Ninth Mile Corner, Obioma, Umuase, Abor and Akama-Amankwo were $20.00 \mathrm{mg} / \mathrm{L}$, $78.50 \mathrm{mg} / \mathrm{L}, \quad 60.00 \mathrm{mg} / \mathrm{L}, \quad 32.40 \mathrm{mg} / \mathrm{L}$ and $28.14 \mathrm{mg} / \mathrm{L}$, respectively. The mean values of Calcium Hardness of the groundwater samples from Ninth Mile Corner, Obioma,
Umuase, Abor and Akama-Amankwo were $10.50 \mathrm{mg} / \mathrm{L}$, $54.50 \mathrm{mg} / \mathrm{L}, \quad 42.00 \mathrm{mg} / \mathrm{L}, \quad 13.90 \mathrm{mg} / \mathrm{L} \quad$ and $10.05 \mathrm{mg} / \mathrm{L}$ respectively whereas mean values of Magnesium Hardness as shown on Table 3.1 from Ninth Mile Corner, Obioma, Umuase, Abor and Akama-Amankwo were $1.50 \mathrm{mg} / \mathrm{L}$, $4.00 \mathrm{mg} / \mathrm{L}, 3.00 \mathrm{mg} / \mathrm{L}, 1.60 \mathrm{mg} / \mathrm{L}, 1.65 \mathrm{mg} / \mathrm{L}$. These results also showed variation in space.

As shown in Table 3.2, the mean values of Iron of the groundwater samples from Ninth Mile Corner, Obioma, Umuase, Abor and Akama-Amankwo were $0.05 \mathrm{mg} / \mathrm{L}$, 
$0.03 \mathrm{mg} / \mathrm{L}, 0.05 \mathrm{mg} / \mathrm{L}, 0.04 \mathrm{mg} / \mathrm{L}$ and $0.03 \mathrm{mg} / \mathrm{L}$ respectively and the mean values of Calcium ion of the groundwater samples from Ninth Mile Corner, Obioma, Umuase, Abor and Akama-Amankwo were $5.60 \mathrm{mg} / \mathrm{L}, \quad 44.75 \mathrm{mg} / \mathrm{L}$, $31.28 \mathrm{mg} / \mathrm{L}, 9.05 \mathrm{mg} / \mathrm{L}$ and $4.50 \mathrm{mg} / \mathrm{L}$ respectively. Table 3.2 also showed that the mean values of Magnesium ion of the groundwater samples from Ninth Mile Corner, Obioma, Umuase, Abor and Akama-Amankwo were $0.15 \mathrm{mg} / \mathrm{L}$, $0.46 \mathrm{mg} / \mathrm{L}, 0.28 \mathrm{mg} / \mathrm{L}, 0.14 \mathrm{mg} / \mathrm{L}$ and $0.15 \mathrm{mg} / \mathrm{L}$ respectively. However, as shown in Table 3.3, Total Coliform and E.coli showed zero mean values in the study sites.

Table 3.2. Spatio-Temporal Variation of Chemical Properties of Groundwater Quality Characteristics in the Study Area.

\begin{tabular}{|c|c|c|c|c|c|c|c|c|c|c|c|c|c|}
\hline S/no & Parameters & Units & Who std & \multicolumn{10}{|c|}{ sample result } \\
\hline & \multirow{5}{*}{$\begin{array}{l}\text { Sample } \\
\text { identificatio } \\
\mathrm{n} / \text { location }\end{array}$} & & & \multicolumn{2}{|l|}{$\mathrm{A}$} & & & & \multicolumn{2}{|l|}{$E$} \\
\hline & & & & \multirow{2}{*}{\multicolumn{2}{|c|}{$\begin{array}{l}\text { Ninth Mile } \\
\text { Corner }\end{array}$}} & \multirow{2}{*}{\multicolumn{2}{|c|}{$\begin{array}{l}\text { B } \\
\text { Obioma }\end{array}$}} & \multirow{2}{*}{\multicolumn{2}{|c|}{$\begin{array}{l}\mathrm{C} \\
\text { Umuase Ngwo }\end{array}$}} & \multirow{2}{*}{\multicolumn{2}{|c|}{$\begin{array}{l}\text { D } \\
\text { Ubiekpo Abor }\end{array}$}} & \multirow{2}{*}{\multicolumn{2}{|c|}{$\begin{array}{l}\text { Akama Amankwo } \\
\text { Ngwo-uno }\end{array}$}} \\
\hline & & & & & & & & & & & & & \\
\hline & & & & \multicolumn{2}{|c|}{ Seasons } & \multicolumn{2}{|c|}{ Seasons } & \multicolumn{2}{|c|}{ Seasons } & \multicolumn{2}{|c|}{ Seasons } & \multicolumn{2}{|c|}{ Seasons } \\
\hline & & & & Dry & Rainy & Dry & Rainy & Dry & Rainy & Dry & Rainy & Dry & Rainy \\
\hline \multirow{17}{*}{2.} & Chemical & & & & & & & & & & & & \\
\hline & Analysis & & & & & & & & & & & & \\
\hline & $\begin{array}{l}\text { Total } \\
\text { Hardness }\end{array}$ & $\mathrm{mg} / \mathrm{LCaCo}_{3}$ & $\begin{array}{l}100.00- \\
200.00\end{array}$ & 12.00 & 8.00 & 58.50 & 59.00 & 45.00 & 43.00 & 15.50 & 12.00 & 11.70 & 7.00 \\
\hline & Chlorides & $\mathrm{mg} / \mathrm{L}$ & 200.00 & 7.40 & 2.13 & 8.62 & 3.55 & 8.00 & 2.84 & 7.39 & 2.13 & 7.94 & 2.84 \\
\hline & Chlorides as & & & & & & & & & & & & \\
\hline & Sodium & $\mathrm{mg} / \mathrm{L}$ & & 9.15 & 3.51 & 11.00 & 5.86 & 9.35 & 4.69 & 9.115 & 3.51 & 10.10 & 4.69 \\
\hline & Chloride & & & & & & & & & & & & \\
\hline & Sulphates & $\mathrm{mg} / \mathrm{L}$ & 200.00 & 18.19 & 9.21 & 47.30 & 23.19 & 25.10 & 12.05 & 18.20 & 9.21 & 24.15 & 12.05 \\
\hline & Nitrate & $\mathrm{mg} / \mathrm{L}$ & 50.00 & 1.04 & 0.24 & 1.15 & 0.29 & 1.05 & 0.25 & 1.01 & 0.17 & 1.00 & 0.15 \\
\hline & Silica & & & 7.80 & 8.02 & 8.50 & 10.90 & 8.00 & 10.50 & 5.00 & 6.07 & 4.50 & 5.82 \\
\hline & $\begin{array}{l}\text { Total } \\
\text { Alkalinity }\end{array}$ & $\mathrm{mg} / \mathrm{LCaCO}_{3}$ & 100.00 & 20.00 & 5.00 & 78.50 & 54.00 & 60.00 & 36.00 & 32.40 & 12.00 & 28.14 & 7.00 \\
\hline & $\begin{array}{l}\text { Calcium } \\
\text { Hardness }\end{array}$ & $\mathrm{mg} / \mathrm{LCaCO}_{3}$ & 200.00 & 10.50 & 7.00 & 54.50 & 56.00 & 42.00 & 41.00 & 13.90 & 11.00 & 10.05 & 6.00 \\
\hline & $\begin{array}{l}\text { Magnesium } \\
\text { Hardness }\end{array}$ & $\mathrm{mg} / \mathrm{LCaCO}_{3}$ & 1.00 & 1.50 & 1.00 & 4.00 & 3.00 & 3.00 & 2.00 & 1.60 & 1.00 & 1.65 & 1.00 \\
\hline & Iron & $\mathrm{mg} / \mathrm{L}$ & $\begin{array}{l}0.05- \\
00.30\end{array}$ & 0.05 & 0.25 & 0.03 & 0.15 & 0.05 & 0.25 & 0.04 & 0.20 & 0.03 & 0.15 \\
\hline & Calcium Ion & $\mathrm{mg} / \mathrm{L}$ & 50.00 & 05.60 & 2.80 & 44.75 & 22.40 & 31.28 & 16.40 & 9.05 & 4.40 & 4.50 & 2.40 \\
\hline & $\begin{array}{l}\text { Magnesium } \\
\text { ion }\end{array}$ & $\mathrm{mg} / \mathrm{L}$ & 50.00 & 0.15 & 0.30 & 0.46 & 0.90 & 0.28 & 0.60 & 0.14 & 0.30 & 0.15 & 0.30 \\
\hline & Manganese & & & NIL & NIL & NIL & NIL & NIL & NIL & NIL & NIL & NIL & NIL \\
\hline
\end{tabular}

Table 3.3. Spatio-Temporal Variation of Microbiological Properties of Groundwater Quality Characteristics in the Study Area.

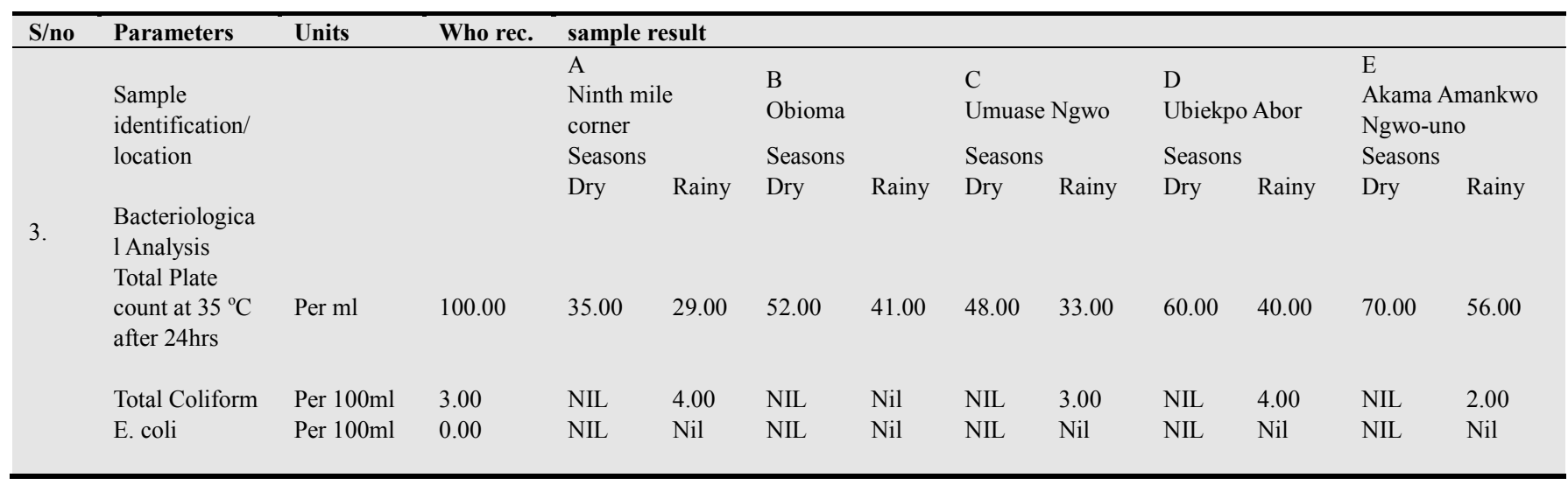

\subsection{Spatial Distribution of Groundwater Samples in the Study Area During the Rainy Season}

Table 3.2 showed the mean values of temperature for the groundwater samples from Ninth Mile Corner, Obioma, Umuase, Abor and Akama-Amankwo respectively were $29.50^{\circ} \mathrm{C}, 29.00^{\circ} \mathrm{C}, 26.00^{\circ} \mathrm{C}, 26.00^{\circ} \mathrm{C}$ and $26.50^{\circ} \mathrm{C}$. The results showed variations in temperature in the various sites. As shown in Table 3.2, the mean values of $\mathrm{pH}$ for the groundwater samples from Ninth Mile Corner, Obioma, Umuase, Abor and Akama-Amankwo were 5.60, 6.80, 6.20, 5.00 and 5.00 whereas the mean values of electrical conductivity for the groundwater samples from Ninth Mile Corner, Obioma, Umuase, Abor, and Akama-Amankwo were $71.30 \mu \mathrm{s} / \mathrm{cm}, 233.60 \mu \mathrm{s} / \mathrm{cm}, 201.00 \mu \mathrm{s} / \mathrm{cm}, 105.00 \mu \mathrm{s} / \mathrm{cm}$ and $41.60 \mu \mathrm{s} / \mathrm{cm}$ as shown in Table 3.2. These results showed 
variation in space.

The mean values of Total Solids for the groundwater samples from $9^{\text {th }}$ Mile Corner, Umuase, Obioma, Abor and Akama-Amankwo were $46.38 \mathrm{mg} / \mathrm{L}, \quad 151.50 \mathrm{mg} / \mathrm{L}$, $130.69 \mathrm{mg} / \mathrm{L}, 68.74 \mathrm{mg} / \mathrm{L}$ and $27.07 \mathrm{mg} / \mathrm{L}$ as shown in Table 3.2. while the mean values of Total Hardness of the groundwater samples from Ninth Mile Corner, Obioma, Umuase, Abor, and Akama-Amankwo were $8.00 \mathrm{mg} / \mathrm{L}$, $59.00 \mathrm{mg} / \mathrm{L}, \quad 43.00 \mathrm{mg} / \mathrm{L}, \quad 12.00 \mathrm{mg} / \mathrm{L} \quad$ and $\quad 7.00 \mathrm{mg} / \mathrm{L}$ respectively. Results also show that the mean values of Total Alkalinity as shown in Table 3.2 of the groundwater samples from Ninth Mile Corner, Obioma, Umuase, Abor and AkamaAmankwo were $5.00 \mathrm{mg} / \mathrm{L}, \quad 54.00 \mathrm{mg} / \mathrm{L}, \quad 36.00 \mathrm{mg} / \mathrm{L}$, $12.00 \mathrm{mg} / \mathrm{L}$ and $7.00 \mathrm{mg} / \mathrm{L}$ respectively.

The mean values of Calcium Hardness of the groundwater samples from Ninth Mile Corner, Obioma, Umuase, Abor and Akama-Amankwo were $7.00 \mathrm{mg} / \mathrm{L}, \quad 56.00 \mathrm{mg} / \mathrm{L}$, $41.00 \mathrm{mg} / \mathrm{L}, 11.00 \mathrm{mg} / \mathrm{L}$ and $06.00 \mathrm{mg} / \mathrm{L}$ whereas, the mean values of magnesium Hardness of the groundwater samples from Ninth Mile Corner, Obioma, Umuase, Abor and AkamaAmankwo were $5.60 \mathrm{mg} / \mathrm{L}, 6.80 \mathrm{mg} / \mathrm{L}, 6.20 \mathrm{mg} / \mathrm{L}, 5.00 \mathrm{mg} / \mathrm{L}$ and $5.50 \mathrm{mg} / \mathrm{L}$. Results showed that the mean values of Iron of the groundwater samples from Ninth Mile Corner, Obioma, Umuase, Abor and Akama-Amankwo were $0.25 \mathrm{mg} / \mathrm{L}$, $0.15 \mathrm{mg} / \mathrm{L}, 0.25 \mathrm{mg} / \mathrm{L}, 0.20 \mathrm{mg} / \mathrm{L}$ and $0.15 \mathrm{mg} / \mathrm{L}$ and as shown in Table 3.2, the mean values of Calcium ion of the groundwater samples from Ninth Mile Corner, Obioma, Umuase, Abor and Akama-Amankwo were $2.80 \mathrm{mg} / \mathrm{L}$, $22.40 \mathrm{mg} / \mathrm{L}, 16.40 \mathrm{mg} / \mathrm{L}, 4.40 \mathrm{mg} / \mathrm{L}$ and $2.40 \mathrm{mg} / \mathrm{L}$.

The mean values of Magnesium Ion as shown in Table 3.2, of the groundwater samples from Ninth Mile Corner, Obioma, Umuase, Abor and Akama-Amankwo were $0.30 \mathrm{mg} / \mathrm{L}$, $0.90 \mathrm{mg} / \mathrm{L}, 0.60 \mathrm{mg} / \mathrm{L}, 0.30 \mathrm{mg} / \mathrm{L}$ and $0.30 \mathrm{mg} / \mathrm{L}$ respectively whereas the mean values of Total Coliform for the groundwater samples showed 4.00per $100 \mathrm{ml}$ in Ninth Mile Corner, Nil in Obioma, 3.00 per $100 \mathrm{ml}$ in Umuase, 4.00 per $100 \mathrm{ml}$ in Abor and 2.00 per $100 \mathrm{ml}$ in Akama-Amankwo.

\section{Discussion}

Table 3.1 showed the mean temperature value from Ninth Mile Corner, Obioma, Umuase, Abor and Akama-Amankwo ranges from $18.50^{\circ} \mathrm{C}$ to $21.00^{\circ} \mathrm{C}$ in the dry season. It showed that Abor has the lowest mean temperature $18.50^{\circ} \mathrm{C}$ while Ninth Mile Corner has the highest mean temperature $21.00^{\circ} \mathrm{C}$. During the rainy season, Ninth Mile Corner showed the highest mean temperature, $29.50^{\circ} \mathrm{C}$ whereas Umuase and Abor showed the lowest mean temperature of $26.00^{\circ} \mathrm{C}$. The result showed that there were variations in temperature in both seasons. Higher groundwater temperature in the rainy season could be because of energy released as water builds up in the reservoirs.

Table 3.1, show spatio-temporal variations in $\mathrm{pH}$ of water samples. Ninth Mile Corner, showed the lowest mean value of $\mathrm{pH}$ (7.02) and Akama-Amankwo showed the highest mean value of $\mathrm{pH}$ (8.11) during the dry season whereas Abor and Akama-Amankwo showed the lowest mean values of $\mathrm{pH}$
(5.00) and Obioma showed the highest mean values of $\mathrm{pH}$ (6.80) during the rainy season. The dry season results were tending towards alkalinity while the rainy season results were tending towards acidity. Higher acidity in the rainy season may be as a result of higher concentration of exchangeable cations (Calcium and magnesium) in the water samples (Table 3.2) and this may also be a result of water recharge in the aquifers during the rainy season that brings dissolved nutrients with it. The dry season results in the five locations did not exceed WHO permissible limits whereas some locations in the rainy season exceeded WHO permissible limits such as Ninth Mile Corner, Abor and Akama. This could be as a result of anthropogenic activities in and around the locations (Krauskopt and Bird, 1994).

Table 3.1 showed that the mean values of electrical conductivity from Ninth Mile Corner, Obioma, Umuase, Abor and Akama-Amankwo were $50.70 \mu \mathrm{s} / \mathrm{cm}, 198.80 \mu \mathrm{s} / \mathrm{cm}$, $175.80 \mu \mathrm{s} / \mathrm{cm}, 80.35 \mu \mathrm{s} / \mathrm{cm}$ and $20.70 \mu \mathrm{s} / \mathrm{cm}$ in the dry season and $71.30 \mu \mathrm{s} / \mathrm{cm}, 233.00 \mu \mathrm{s} / \mathrm{cm}, 201.00 \mu \mathrm{s} / \mathrm{cm}, 105.70 \mu \mathrm{s} / \mathrm{cm}$ and $41.60 \mu \mathrm{s} / \mathrm{cm}$ in rainy season respectively. From the result, Akama-Amankwo showed the lowest mean value $20.70 \mu \mathrm{s} / \mathrm{cm}$ and Obioma showed the highest mean value, $198.50 \mu \mathrm{s} / \mathrm{cm}$ during the dry season. During the rainy season, Akama showed the lowest mean value $41.60 \mu \mathrm{s} / \mathrm{cm}$ and Obioma showed the highest mean value $233.00 \mu \mathrm{s} / \mathrm{cm}$. The results as well showed variations in both space and time. During aquifer recharge in the rainy season, dissolved salts are brought in with water and as evapotranspiration and deep percolation intensify during the dry season, salts are left behind and its concentration increases within the groundwater. The variations across locations could be associated with the lithological formations composed of halite and gypsum (Tizro et al, 2004).

Total Solids range from $29.00-154.20 \mathrm{mg} / \mathrm{L}$ in the dry season and $27.07-151.50 \mathrm{mg} / \mathrm{L}$ in the rainy season as shown in Table 3.1. The lowest mean values of Total Solids are recorded in Akama-Amankwo for the both seasons and the highest means values of Total solids are recorded in Obioma. The results from both seasons were in conformity with WHO permissible limits.

The mean result of Total Hardness as shown in Table 3.2 varies from $11.70 \mathrm{mg} / \mathrm{L}$ to $58.50 \mathrm{mg} / \mathrm{L}$ in the dry season and from $7.00 \mathrm{mg} / \mathrm{L}$ to $59.00 \mathrm{mg} / \mathrm{L}$ in the rainy season. It was recorded that Akama-Amankwo site showed the lowest mean value in both dry and rainy seasons, $11.70 \mathrm{mg} / \mathrm{L}$ and $7.00 \mathrm{mg} / \mathrm{L}$ whereas Obioma showed the highest mean value in the both seasons, $58.50 \mathrm{mg} / \mathrm{L}$ and $59.00 \mathrm{mg} / \mathrm{L}$. The concentration of total hardness of groundwater samples from Ninth Mile Corner, Obioma, Umuase, Abor and AkamaAmankwo showed, the result were below WHO permissible limits of $100.00 \mathrm{mg} / \mathrm{L}$ to $200.00 \mathrm{mg} / 1 \mathrm{CaCo}_{3}$. Results also showed that the concentration of magnesium hardness observed in the study area is varied from 1.50 to $4.00 \mathrm{mg} / \mathrm{L}$ $\mathrm{CaCo}_{3}$ in the dry season and 1.00 to $3.00 \mathrm{mg} / \mathrm{L} \mathrm{CaCo}_{3}$ in the rainy season as shown in Table 3.2. The result recorded the lowest mean value of magnesium hardness at Ninth Mile Corner and highest mean value at Obioma with the values 
1.50 and $4.00 \mathrm{mg} / \mathrm{L}$ in the dry season and in the rainy season, it recorded the lowest mean value of magnesium hardness $9^{\text {th }}$ Mile Corner, Abor and Akama and the highest mean values at Obioma with the values 1.00 and $3.00 \mathrm{mg} / \mathrm{L}$ respectively. As postulated earlier, during aquifer recharge in the rainy season, dissolved salts are brought in with water and as evapotranspiration and deep percolation intensify during the dry season, salts are left behind and its concentration increases within the groundwater. The variations across locations could be associated with the lithological formations composed of halite and gypsum (Tizro et al, 2004). The spatio-temporal differences in total hardness could be due to dissociation of salts on the various locations (WHO, 2011; Narsimha et al, 2013). Ong et al, (2009) noted that magnesium dissociation mainly comes from the feromagnesium carbonates in sedimentary rocks than the anthropogenic sources (Weiner, 2000; WHO, 2009).

The values of Total Coliform observed in the study area is varied from $2-4$ per $100 \mathrm{ml}$ in the rainy season and it showed zero concentration in the groundwater samples from Ninth Mile Corner, Obioma, Umuase, Abor and Akama-Amankwo during the dry season. Akama-Amankwo recorded the lowest mean value of 2 per $100 \mathrm{ml}$ and Ninth Mile Corner and Abor recorded the highest mean values 4.00 per $100 \mathrm{ml}$ in the rainy season. The result showed that groundwater samples from Ninth Mile Corner and Abor with the values 4.00 per $100 \mathrm{ml}$ exceeded WHO permissible limits for Total Coliform of 03.00 per $100 \mathrm{ml}$. The high coliform populations are an indication of poor sanitary conditions in the locations and this may be owing to unhygienic practices of the residents (Onianwa et al, 2001). That maybe the source of many diseases, the groundwater bacterial contamination will cause typhoid, diarrhea, cramps, nausea and headaches (Harikumar and Kokkal, 2009, Boominathan et al, 2012).

\section{Conclusions}

This study probes the spatio-temporal variation of groundwater quality in $9^{\text {th }}$ Mile Corner, Obioma, Umuase, Abor and Akam-Amankwo in Udi local Government Area of Enugu State. From the study, the physical parameters (Temperature, pH, Electrical Conductivity, Total Solids, Turbidity, Colour, Total Dissolved Solids, Total Suspended Solids), Chemical Parameters(Total Hardness, Chlorides, Chlorides as Sodium Chloride, Magnesium Hardness, Iron, Calcium Ion, Magnesium Ion, Manganese) and Microbiological Parameters (Total Plate Count, Total Coliform, E. Coli) were determined as shown in Table 4.1 and 4.2. The Tables showed that most of the parameters were in consistent with the WHO maximum permissible limits for domestic use except $\mathrm{pH}$ which was not in conformity with WHO permissible limit during the rainy season in Ninth mile, Umuase, Abor and Akama-Amankwo in Udi Local Government Area of Enugu State. Total Hardness as well was not in conformity with WHO limits in the five sites, Ninth Mile Corner, Obioma, Umuase, Abor and Akama-Amankwo in both seasons. Magnesium Hardness was not in conformity with the WHO permissible limits in the five sampling sites during the dry season and in the rainy season only Obioma and Umuase were not in conformity with WHO permissible limits. The result also showed that Total Coliform was not in conformity with WHO limits during the rainy season in Ninth Mile Corner and Abor. These may have negative effect on the quality of groundwater for human consumption in Udi Local Government Area and its environment.

Water, the nectar of life is one of the most important natural resources for all living organisms because it is required for their various activities. From the study, it was concluded that the quality of groundwater in Udi Local Government Area needs little treatment to stabilize the $\mathrm{pH}$ especially during the rainy season by the addition of Calcium Carbonate $\left(\mathrm{CaCO}_{3}\right)$ and also the Total hardness in both season in the study area. Magnesium hardness requires little treatment since excess of it may have laxative effect on human health. It may also cause increased soap consumption and scale deposition in the water distribution system. The Total coliform contamination in Ninth Mile Corner and Abor sites could be attributed to the unhygienic practices of the residence. Total coliform also needs treatment because when found in groundwater supply may cause ill-effect to human health such as cholera, diarrhea and dysentery. Hence, there is need for continuous assessment of the groundwater quality in the study area.

\section{References}

[1] Anikwe, M. A. N., Mbah, C. N., Ezeaku, P. I., \& Onyia, V. N. (2007). Tillage and plastic mulch effects on soil properties and growth and yield of cocoyam (Colocasia esculenta) on an ultisol in southeastern Nigeria. Soil and Tillage Research, 93(2), 264-272.

[2] APHA, AWWA and WEF, (2012) Standard Methods for the Examination of Water and Waste water, 22nd Edition, Washington, DC.

[3] Boominathan, M., Karthick, B., Sameer, A. and Ramachandra, T. V.(2012) Spatial Assessment of Groundwater Quality in Kerala, India. The IUP Journal of Soil and Water Science, 5(1) $44-57$.

[4] Ebrahim, K. H., Ferznja S., Jamat-iostami, M., Ausati, K.H (2011) Assessing Temporal and spatial Variations of Groundwater Quality, A Cases of Kohpayehi-segzi. Journal of Raineland Science, 1(3): $193-201$.

[5] Ezeh, C. C., Ugwu, G. Z., Okonkwo, A. and Okampka, J. (2013) Using the Relationships Between Geoelectrical and Hydrogeological Parameters to Assess Aquifer Productivity in Udi L.G.A, Enugu State, Nigeria. International Research Journal of Geology and Mining, 3(1):9-18.

[6] Fetter C. W. (1993), Contaminant Hydrogeology, Waveland Press, Incorporate Long Grove, Illinoise, 500.

[7] Harikumar, P. S. and Kokkal, K.(2009). Environmental Monitoring Program on Water Quality. Kerala State Council for Science, Technology and Environment, Govt of Kerala, 174. 
[8] Helena B., Pardon R., Vega M., Barrado E., Fernandez J. M. and Fernandez L.,(2002) Temporal Evolution of Groundwater Composition in an Alluvial Aquifer (Pisuerga River, Spain) by Principal Component Analysis Water Resources, 34(3): $807-$ 816.

[9] Kortatsi B.K (2007) Hydrochemical Framework of Groundwater in the Anakobra Basin, Ghana Journal of Aquatic Geochemistry, 1(3): 41 - 74.

[10] Krauskoff, K. B., and Bird, D. K. (1994) Introduction to Geochemistry, 3rd Edition. McGraw-Hill, New York, 640.

[11] Narsimha, A., Sudarshan, V., Srinivasulu, P., Anitha, N. and Parameshwar, V. (2013) An Integrated Approach to Assess the Quality of Groundwater in Post of Cheralapally Area, Rangareddy District, Andhra Pradesh, India. Advances in Applied Science Research, 4(1): 244 - 253.

[12] Njanje T.N., Adamu C. I., Ntekim EEU, Ugbaja A.N., Nejip., Nfor E.N., (2010) Influence of Mine Drainage on Water Quality Along River Nyaba in Enugu, Southeastern Nigeria. African Journal of Environmental in Science and Technology, 4(3): $132-144$.

[13] Offodile, M. E., (2002) Groundwater Study and Development in Nigeria. 2nd Edition. Mecon Geology and Engineering Services Ltd, Jos, 453.

[14] Ong, C. N., Grandjean, A. C., Heaney, R. P., (2009) The Mineral Com position of Water and its Contributions to Calcium and Magnesium Intake. In Calcium and Magnesium in Drinking-Water; Public Health Significance Geneva,World Health Organization 36-58.

[15] Onianwa, P. c., Jaiyeola, O. M., Egekenze, R. N (2001) Heavy Metals Contamination of Top Soils in the Vicinities of Auto- repair Workshops, Gas Stations and Motor Parks in a Nigeria City. Journal of Toxicology and Environmental Chemistry, 84(1-4): $33-39$.

[16] Onwuka, S. O., Ezeh, C. S. and Ekwe, A. C. (2010) Application of Groundwater Technique in the Assessment of Groundwater Quality in Udi and its Environs, South-eastern, Nigeria. Journal of Earth Environmental Sciences, 3(2): 63 78.

[17] Reyment, R. A., (1965) Aspects of the Geology of Nigeria: the Stratigraphy of the Cretaceous and Cenozoic Deposits. University of Ibadan Press, 1459.

[18] Sarukkalige, R. (2012) Geostatistical Analysis of Groundwater Quality In Western Australia, IRACST -International Journal Engineering Science and Technology, 2(4):790 -794.

[19] Tizro, A. T., Voudouris, K. and Vahedi, S.,(2014) Spatial Variation of Groundwater Quality Parameters. A Case Study from a Semiarid Region of Iran. International Bulletin of Water Resources and Development, 1(3): 1 - 14

[20] Weiner, E. R., (2000) Applications of Environmental Chemistry: A Practical Guide for Environmental Professionals. Lewis Publishers Florida, 230.

[21] World Health Organisation (2009) Calcium and Magnesium in Drinking-Water: Public Health Significance. Geneva World Health Organization.

[22] World Health Organisation (2011) Hardness in DrinkingWater Background Document for Development of WHO Guidelines for Drinking-Water Quality WHO, Geneva 1-10. 